\title{
PERMAINAN KIM: KOMPOSISI MUSIK PROGRAMA DALAM FORMAT MUSIK ELEKTRONIK
}

\author{
Diandra Ramadhani Alifa, Rasmida, Martarosa \\ Pascasarjana Institut Seni Indonesia Padangpanjang \\ Email: diandramusic26@gmail.com
}

\begin{abstract}
The KIM game is a traditional Minangkabau game that uses rhymes and numbers. KIM stands for Kesenian Irama Minang (Minang Art Rhythm). The phenomenon that occurs in the current KIM game is the lack of audience awareness of the meaning and message of the rhymes sung by the dendang artis. Departing from this phenomenon, the creator presented a work titled KIM Game: Programa Music Composition in Electronic Music format. The method of creation is carried out with several work groupings: Concept development methods (observation, interviews, data collection and concept formulation) and methods of realizing concepts (exploration, experimentation, and application).
\end{abstract}

Keywords: KIM game, program music, electronic music.

\begin{abstract}
ABSTRAK
Permainan KIM merupakan suatu permainan tradisi Minangkabau yang menggunakan pantun dan angka. KIM tersebut merupakan singkatan dari Kesenian Irama Minang. Fenomena yang terjadi pada permainan KIM saat ini yaitu, kurangnya kesadaran audiens terhadap makna dan pesan dari pantun yang dilantunkan tukang dendang. Berangkat dari fenomena tersebut pengkarya menghadirkan sebuah karya Permainan KIM: Komposisi Musik Programa dalam format Musik Elektronik. Metode penciptaan dilakukan dengan beberapa pengelompokan kerja: Metode pengembangan konsep (observasi, wawancara, pengumpulan data dan perumusan konsep) dan metode mewujudkan konsep (eksplorasi, eksperimentasi, dan aplikasi).
\end{abstract}

Kata kunci: Permainan KIM, Musik Programa, Musik Elektronik.

\section{PENDAHULUAN}

Permainan merupakan sebuah aktifitas rekreasi dengan tujuan bersenang-senang, mengisi waktu luang, atau berolahraga ringan. Permainan biasanya dilakukan sendiri atau bersama-sama (kelompok) (wikipedia.org). Di Minangkabau ada sebuah permainan yang berbentuk kesenian. Kata seni berasal dari bahasa sanskerta, yaitu "sani" yang memiliki makna "pemujaan, persembahan, pelayanan". Pengertian seni menurut Aristoteles "merupakan peniruan terhadap alam tetapi sifatnya harus ideal". Aristoteles menjelaskan dan memaparkan bahwa seni adalah sebuah peniruan terhadap alam yang memiliki sifat tepat guna 
atau ideal, sesuai dengan proporsi alam. Akan tetapi pendapat ini bisa menampik kekuatan seni yang sejatinya bisa diekspresikan bahkan jika sebuah karya tersebut adalah hanya dimiliki oleh imajinasi seseorang dan bersifat tidak mungkin (www.ilmuseni.com).

KIM merupakan suatu permainan tradisi Minangkabau yang menggunakan pantun dan angka. KIM tersebut merupakan singkatan dari Kesenian Irama Minang. Dalam permainan KIM ada namanya tukang dendang yang melantunkan lagu dengan pantun, kemudian pada akhir pantun akan diucapkan angka. Angka tersebut diambil dari sebuah kaleng yang isinya berupa koin yang dimiliki si tukang dendang, kemudian angka dalam kaleng tersebut akan keluar secara acak. Angka akan tertera dalam kertas yang diistilahkan lapiak, kertas ini berbentuk kolom yang terdiri dari 6 baris, terbagi atas 3 kolom, yaitu kolom A B C, masing-masing kolom terdiri dari 10 angka, kemudian bagi pemenang KIM akan diberi hadiah oleh si pemilik acara, hadiahnya pun beragam. Kertas atau lapiak tersebut terdiri dari 5 macam warna (putih, hijau, merah, biru, dan kuning).

Permainan KIM memiliki nilai silaturahmi yang kuat, karena biasanya dilokasi acara pesta pernikahan, alek nagari, apabila ada permainan KIM bermacam-macam masyarakat yang datang untuk mengikuti permainan tersebut, dari yang tidak saling mengenal bisa saling bercengkrama satu sama lain, sangat kecil sekali kemungkinan untuk terjadi keributan pada acara tersebut. Karena mereka fokus melihat dan mengisi angka-angka yang tertera pada kuponnya, berbeda dengan acara-acara pentas malam hiburan, atau pesta pernikahan lainnya yang biasanya pada malam hari sering disuguhkan dengan minuman alkohol, lalu mabuk-mabukan, dan berjogetjoget yang tidak berfaedah. Menurut Aristoteles "menolak pendidikan musik yang hanya memberikan kenikmatan vulgar (1341b9-12) pada pendengarnya-kenikmatan permainan bunyi-bunyian. Orang-orang yang menyukainya memiliki selera estetis yang rendah " (Suryajaya, 2016: 65).

Permainan ini bersifat adil, karena apabila hadiah yang dikeluarkan cuma 1 unit namun pemenangnya lebih dari satu, permainan KIM pun memiliki aturan yaitu hadiah dibagi 2 atau dikeluarkan 1 unit hadiah lagi dengan nominal yang berbeda. Jadi tidak ada rasa berkecil hati atau kecewa untuk para pemenang, dan bagi yang tidak mendapatkan hadiah sama sekali pun mereka tidak berkecil hati, karena mereka semata-mata mengikuti permainan, tidak dipungut biaya apapun.

Pada zaman sekarang ini permainan KIM sangat berkembang pesat, karena peminatnya pun semakin banyak, otomatis pelaku KIM pun semakin banyak khususnya kota Bukittinggi. Dengan berkembangnya permainan ini tentu ada pula beberapa pergeseran atau perubahan kaidah-kaidah yang ada pada permainan KIM yang sebetulnya. Di Bukittinggi pada umumnya hampir setiap acara pesta pernikahan diadakan permainan KIM, tidak hanya pada acara pesta pernikahan saja, permainan ini merambah hingga ke acara instansi perkantoran, dinas pendidikan, dan sebagainya.

Di Bukittinggi ada satu pelaku sekaligus pakar KIM bernama Inyiak Baron kelahiran 1933. Menurut beliau 
permainan KIM muncul pada tahun 1945, beliau mengadakan permainan KIM saat perayaan Kemerdekaan RI yang berlokasi di Tembok, Bukittinggi, pada saat itu permainan KIM tidak menggunakan alat musik seperti pada zaman sekarang, hanya bernyanyi (badendang) tanpa iringan musik, tanpa alat pengeras suara, formasi permainannya pun audiens mengelilingi tukang dendang dalam keadaan duduk. Bentuk kertas (lapiak) hanya terdiri dari 3 baris saja, dan angka-angka yang terdapat pada kertas tersebut dibuat menggunakan stempel, tidak di print seperti sekarang ini, dan koin nya diukir dengan tinta hitam. Pada tahun 1954 beliau merantau ke Malaysia terdapat permainan jenis ini namun berbeda nama, di Indonesia khususnya Minangkabau dinamakan KIM (Kesenian Irama Minang), kemudian di Malaysia bernama Loto. Perbedaannya terletak pada jumlah angka yang dimainkan, KIM berjumlah 90 angka, Loto berjumlah 75 angka, kemudian Loto tidak menggunakan pantun seperti permainan KIM, tetapi hanya menggunakan kalimat " 2 ekor, 4 kepala, 42 dibilang”. Angka KIM yang berjumlah 90 memiliki beberapa makna, yaitu Minangkabau memiliki 3 nagari 9 rantau, bujang 9 (Inyiak Baron, 10 November 2018).

Di balik tugasnya sebagai tukang dendang ia bertanggung jawab sebagai hakim, yaitu bersikap adil, tegas, jujur, menentukan siapa yang berhak menang dengan murni tanpa merubah atau memalsukan angka yang teradapat pada kupon atau lapiak. Pada tahun 1964 beliau merantau ke Medan, permainan KIM mulai diiringi dengan gendang hingga tahun 1967.
Dapat dibuktikan dengan pantun yang masih sering diucapkan pada zaman sekarang, yaitu,

"ka ladang marilah ka ladang,

Ka ladang ka tanah deli,

Lah sudah batu digoyang,

Bamain kito mulai."

Tanah deli yang terdapat dalam pantun tersebut menjadi bukti bahwa pada saat itu ia sedang merantau dengan membawa permainan KIM ke Sumatera Utara. Pantun tersebut masih digunakan hingga zaman sekarang bahkan dikomersilkan dalam bentuk kaset / VCD.

Beberapa pergeseran atau perubahan kaidah-kaidah permainan KIM adalah:

a) Adanya sistem atau aturan mengundi hadiah atau yang diistilahkan cabuik nomor. Dalam aturan permainan yang sebenarnya menurut Inyiak Baron, tukang dendang, panitia acara, atau pemilik acara tidak berhak untuk melakukan aturan ini, kecuali atas persetujuan si pemenang yang lebih dari 1 orang, karena apabila tanpa ada persetujuan dari si pemenang tentu akan ada yang merasa kecil hati dari salah seorang diantara pemenang.

b) Pantun yang dilantunkan atau digunakan pada saat ini banyak yang tidak sesuai dengan tutur bahasa adat Minangkabau. Seperti, "halimah si jando kayo, si inam pelayan seksi." Secara tidak langsung bahasa minang yang dikenal dengan kieh (kiasan), bertutur kata dengan sopan dan baik berubah menjadi frontal tanpa memikirkan kondisi disekelilingnya. Dalam konteks ini secara tidak langsung audiens 
tidak sadar, bahwa ada unsur menghakimi seseorang walaupun terkesan guyonan.

c) Ada beberapa pelaku KIM yang tidak jujur dalam melakukan permainan tersebut, yaitu menyisihkan / memberi tanda pada koin angka di dalam kaleng untuk berusaha memenangkan seseorang.

Bagi sebagian masyarakat ada yang berpandangan negatif terhadap permainan KIM. Ada yang berpendapat atau memandang KIM ini adalah permainan judi. Menurut hasil wawancara kepada Inyiak Baron, beliau mengatakan bahwa permainan ini bukanlah permainan judi, namun bisa dijadikan permainan judi, tetapi tergantung kepada orang yang mengikuti permainan tersebut, dan tergantung kepada penyelenggara acara. Bukan berarti permainan KIM ini memperjual belikan kupon atau lapiak, tidak terlepas pada unsur dasarnya bahwa permainan KIM ini adalah hiburan. Penciptaan seni musik barat yang akan pengkarya ciptakan berdasarkan fenomena hiburan permainan KIM yang berada di Bukittinggi berdasarkan hasil riset dari data wawancara dan juga pengalaman empiris pengkarya yang sering terlibat dalam mengiringi hiburan permainan KIM. Hasil dari keseluruhan yang dapat pengkarya rangkum dari bentuk deskripsi yaitu, permainan KIM dapat dilihat dari segi sosial masyarakat, pandangan negatif masyarakat, dan dari pelaku KIM.

Keinginan pengkarya dalam mengangkat ide yang bersumber dari pengalaman empiris ini adalah ingin menyadarkan kembali bahwa permainan KIM bukan semata-mata hiburan, tetapi ada sisi pembelajaran dalam melestarikan budaya Minangkabau yaitu, pantunnya yang berupa kiasan tidak terlepas dari kato nan ampek, mandaki, manurun, malereng, mandata, kemudian ingin mengembalikan kembali unsur-unsur permainan sebagaimana mestinya, dan ingin memberi suatu penyadaran untuk masyarakat bahwa media permainan ini adalah salah satu upaya untuk mempertahankan cara berpepatah-petitih Minangkabau.

\section{KAJIAN TEORI}

Dalam musik atau kesenian secara umum, apa yang penting bagi Aristoteles bukan sekedar menikmati, tetapi 'menikmati secara tepat' (khairein orthos). Disini kita bertemu lagi dengan kata orthos, ketepatan atau kesesuaian, yang pernah kita jumpai dalam plato. Kali ini objek ketepatan itu adalah keutamaan moral masyarakat. Menikmati musik secara tepat bukan hanya 'mendengar musik'- menikmati permainan harmoni, ritme, dan melodimelainkan juga memahami signifikasi sosialnya. Artinya, dalam penikmatan yang tepat atas musik kita memperoleh pengertian tentang keutamaan moral suatu masyarakat (Suryajaya, 2016: 65).

Karya ini diwujudkan kedalam jenis karya musik programa dengan perwujudan musik elektronik yang didalamnya ada berupa teknik eksplorasi, eksperimen bunyi, sebagaimana dijelaskan oleh Karl Edmund bahwa: Musik programa adalah peristiwa dari luar cerita atau situasi yang diwujudkan melalui musik sehingga tercipta asosiasi peristiwa saat musik dibunyikan. Musik programa tidak mengikuti hukum bentuk musik seperti Sonata, Rondo, dan sebagainya, tetapi terikat 
pada cerita. Instrumentasi dan orkestrasi dalam musik programa sangat penting untuk menirukan bunyi tertentu, dari bunyi realistis (bunyi lonceng) sampai bunyi yang simbolis (Leitmotiv) yang mewakili situasi tertentu dan diolah sampai ke bentuk karya musik (Prier, 1993: 198).

\begin{tabular}{cr}
\multicolumn{2}{c}{ Istilah Programmatic Music yang } \\
artinya musik yang
\end{tabular}
menginterpretasikan sebuah cerita, dongeng, lukisan dan lain-lain. Dikenal juga dengan istilah ilustrative music. Dieter Mack dalam buku Sejarah Musik Jilid 3 (1995: 138) mengelompokkan musik programa dalam beberapa bagian, diantaranya yaitu komposisi musik instrumental yang menggambarkan sebuah rangkaian kejadian (Narrative); menggambarkan suatu peristiwa yang mempunyai bentuk, ruang, dan waktu (Descriptive); menggambarkan karakter yang tersirat (Applelative); dan mengekspresikan suatu filosofi (Ideational).

Musik elektronik adalah mengarah pada peralatan musik dimana generator-generator (yang bisa memproduksikan gelombanggelombang baik yang paling sederhana-"sinus"- maupun yang paling kompleks- "white noise"- atau "impulse" digunakan sebagai alat musik biasa. Namun oleh karena tuntutan otonomi estetis (dibandingkan dengan musik instrumental/vocal yang biasa) teknik komposisi, masalah bentuk atau form, serta kumpulan materinya sendiri harus berbeda sekali dari pada caracara yang konvensional. Tentu saja kenyataan ini juga sangat mempengaruhi proses garapan, dimana suatu fase eksperimental sebelum proses garapan sendiri menjadi sangat penting. Dilihat dari sisi lain, kemungkinan besar bahwa seorang composer hanya dapat menciptakan suatu konsep formal (misalnya suatu struktur nada atau bunyi dengan jarak interval yang ditentukan secara abstrak dan tanpa diketahui dampak auditifnya, karena strukturnya saja yang diutamakan dari pada warnanya) yang dapat diwujudkan secara elektronis (Mack, 1995: 58).

Musik elektronik merupakan mesin yang dapat memainkan instrument menjadi harmonic musik tanpa benar-benar harus memainkan instrument musik secara langsung. Musik elektronik didasarkan pada komposisi secara elektrik yang menghasilkan suara yang dibuat oleh generator. Musik elektronik dapat dimainkan dari berbagai software musik maupun alat-alat yang disediakan, sehingga alat-alat ini dapat diharmonisasikan sesuai dengan yang kita mau.

Ben M Pasaribu (2008: 21) mengatakan, bahwa pada dasarnya musik elektronik mengeksplorasi keragaman sumber bunyi natural maupun artificial dengan proses elektronik. Pendapat inilah yang menjadi salah satu landasan pengkarya untuk mencoba mengeksplorasi bunyi kaleng KIM dan menjadikan hasil dari eksplorasi bunyi kaleng KIM tersebut menjadi sebuah bunyi baru,atau menjadi sound pendukung.

Selain dari fenomena permainannya pengkarya mengangkat sebuah lagu yang dahulunya dipakai untuk permainan KIM, sampai sekarang lagu tersebut masih dipakai dalam permainan KIM hari ini, dan kemudian dipopulerkan oleh elly kasim pada tahun 1963 yang berjudul 
"karanggo". Menurut inyiak Baron lagu ini sudah ada sejak beliau bekerja menjadi tukang dendang KIM namun dikomersilkan oleh elly kasim pada tahun 1963. Kemudian pengkarya ingin menghadirkan pola ritme musik yang biasanya dipakai untuk bermain $\mathrm{KIM}$, pola ritme musik atau jenis musik ini dinamakan joget gamat. Berangkat dari fenomena permainan, lagu, pola ritme ini pengkarya ingin mewujudkan kedalam sebuah karya musik elektronik. Berdasarkan lagu dengan judul karanggo serta pola ritme pengkarya tetap mengusung ciri-ciri ini sebagai bentuk mempertahankan nilai dari esensi lagu yang harus dimiliki dari KIM yang di proyeksikan dalam bentuk musik elektronik.

\section{METODE PENCIPTAAN}

Metode penciptaan yang dilakukan dalam perwujudan karya seni ini dilakukan dengan beberapa pengelompokan kerja. Adapun tahapan langkah kerja dalam proses penciptaan komposisi musik Permainan KIM: Komposisi Musik Programa dalam Format Musik Elektronik adalah sebagai berikut: (1) Metode Pengembangan Konsep (Observasi, Wawancara, Pengumpulan data, dan Perumusan Konsep); (2) Metode Mewujudkan Konsep (Eksplorasi, Eksperimentasi, dan Aplikasi).

\subsection{Pengembangan Konsep Karya}

Metode penciptaan berkaitan dengan aspek formal, yaitu aspek sifat keteraturan susunan artistik yang melekat dalam karya seni yang hendak dicipta dan dapat menjadi karakter pembeda sehingga menjadi karakter istimewa. Metode penciptaan meliputi dua tahap (1) metode untuk mengembangkan konsep, dan (2) metode untuk mewujudkan konsep (Bambang Sunarto, 2013:87). Berdasarkan metode penciptaan yang dikemukaan Bambang Sunarto dalam proses penciptaan karya musik ini pengkarya melakukan pendekatan metode penciptaan konsep yaitu:

Proses penciptaan karya musik Permainan KIM dalam Musik Programa ini melalui metode pengembangan konsep melakukan sebuah observasi, wawancara, pengumpulan data mengenai Permainan KIM. Permainan KIM ini memang tidak memiliki unsur musikal, melainkan ekstra musical, namun berangkat dari sebuah melodi lagu yang berjudul "Karanggo" pengkarya mengaitkan spirit yang terjadi pada Permainan KIM. Observasi dilakukan untuk melihat dan berkomunikasi langsung dengan penikmat / pecandu KIM, dan pelaku KIM. Agar dapat deskripsi umum serta informasi lebih lengkap tentang Permainan KIM yang eksis pada hari ini.

Wawancara dilakukan unuk mencari info lebih dalam mengenai makna yang terkandung, dan kenikmatan yang terjadi pada permainan KIM. Pengkarya juga menjadi salah satu informan dalam fenomena ini, dikarenakan pengkarya juga terlibat sebagai pelaku (pemain orgen tunggal) yang sering mengiringi permainan KIM.

\subsection{Metode Mewujudkan konsep}

Berangkat dari fenomena permainan KIM tersebut pengkarya mewujudkan permainan harmoni, ritme, melodi, bentuk musik dan pesan moral kepada masyarakat melalui musik elektronik. Musik 
elektronik menjadi suatu bentuk ketertarikan pengkarya dalam menciptakan musik dengan memberi nilai edukasi dan moral dalam ruang lingkup masyarakat.

Melakukan Eksplorasi bunyi merekam kaleng tukang dendang yang digunakan saat permainan berlangsung, lalu mencoba untuk bereksperimen dengan hasil rekaman tersebut menjadi suatu bunyi yang baru, baik itu berbentuk instrument perkusi atau melodi. Kemudian hasil audio tersebut pengkarya pakai kedalam garapan komposisi musik elektronik. Teknik eksplorasi ini dinamakan sampling record. Sampling adalah proses pengambilan contoh suara melalui rekaman, untuk selanjutnya sample tersebut diolah (edit) dengan software yang disebut sampler. Hasil dari proses sampling ini berupa file berformat WAV.

Melakukan Eksperimen dari hasil eksplorasi yang telah dilakukan. Setelah dilakukan proses sampling kemudian hasil audio ini diolah (edit) melalui fitur-fitur yang telah diciptakan dari software yang pengkarya gunakan. Fitur tersebut mewakili ide dan gagasan pengkarya untuk mengekspresikan hasil audio kaleng KIM tesebut. Beberapa fitur yang mendukung untuk metode eksperimen ini adalah attack, sustain, decay, release, cutoff, frequency, key mapping, effects.

\section{HASIL DAN PEMBAHASAN}

Permainan KIM yang dilihat dari sudut pandang pengkarya terhadap pelaku yang sering terlibat pada permainan tersebut menjadikan sumber inspirasi bagi pengkarya untuk menggagas komposisi musik Permainan KIM dalam Musik Programa dengan menggunakan teknik musik elektronik dimana permainan KIM dapat dilihat sebagai permainan yang sangat menarik dari mayoritas masyarakat, memunculkan sisi penyadaran dan penawaran penyampaian makna dari pantun yang terkandung pada permainan KIM. Maka dari itu karya ini diberi judul Permainan KIM: Komposisi Musik Programa Dalam Format Musik Elektronik.

Konsep musik dari judul diatas adalah konsep Musik Programa dalam format Musik Elektronik. Konsep komposisi ini merupakan mengelompokkan musik programa dalam beberapa bagian, diantaranya yaitu komposisi musik instrumental yang menggambarkan sebuah rangkaian kejadian (Narrative); menggambarkan suatu peristiwa yang mempunyai bentuk, ruang, dan waktu (Descriptive); menggambarkan karakter yang tersirat (Applelative); dan mengekspresikan suatu filosofi (Ideational). (Dieter Mack, 1995:138).

Musik Elektronik disisi lain melibatkan mesin yang dapat memainkan instrument menjadi harmonic musik tanpa benar-benar harus memainkan instrument musik secara langsung. Musik elektronik didasarkan pada komposisi secara elektrik yang menghasilkan suara yang dibuat oleh generator. Musik elektronik dapat dimainkan dari berbagai software musik maupun alatalat yang disediakan, sehingga alatalat ini dapat diharmonisasikan sesuai dengan yang kita mau.

Penciptaan musik Permainan KIM digagas dengan teknik musik elektronik, dimana unsur musik musikal yang dipakai bersumber dari melodi sebuah lagu yang berjudul "Karanggo" (riset, wawancara) bahwa lagu ini sudah ada sejak KIM 
dilakukan. Penggunaan unsur dan skala musik dari metoda Arnold Schoenbert yang mana kebebasan dalam memilih wilayah nada tidak terbatas atau sistem deret dari dua belas nada kromatik, artinya dua belas nada itu boleh digunakan dalam penggarapan komposisi musik. Selain dari itu, teknik komposisi musik barat juga tetap digunakan diantaranya seperti canon, unisono, dan lain sebagainya.

Berikut contoh melodi yang menjadi sumber musikal pada karya musik Permainan KIM: Komposisi Musik Programa Dalam Format musik elektronik.

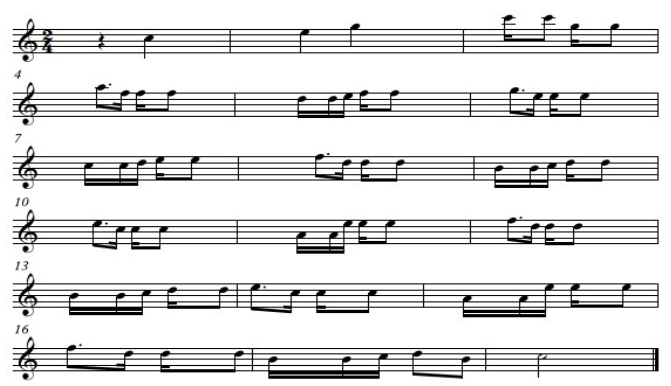

Setelah melakukan eksplorasi dan eksperimen, pengkarya menuangkan karya tersebut kedalam musik programa melalui musik elektronik. Bentuk musik programa yang dihadirkan pada komposisi Musik Barat berupa menceritakan suatu peristiwa dari isi pantun-pantun KIM yang menggambarkan suatu daerah khususnya Bukittinggi, lalu menyampaikan pesan moral yang terkandung pada pantun-pantun KIM. Beberapa teknik komposisi yang akan pengkarya hadirkan yaitu, melodi lagu tersebut yang akan dikaitkan dengan angka 3 (jumlah baris yang ada pada lapiak KIM), angka 3 tersebut diinterpretasikan kedalam ilmu musik yaitu modes frhygian, kemudian angka KIM yang berjumlah 90 juga akan menjadi teknik komposisi, yaitu menghadirkan nada ke-9 dan chord add9 menjadi dominan pada komposisi musik elektronik ini. Teknis penampilan karya ini mengacu pada satu buah kertas atau lapiak KIM, dalam lapiak tersebut terdapat jumlah 30 angka, terdiri dari 6 baris dan 3 buah kolom, kolom A, B, C. Angka tersebut nantinya akan pengkarya susun sesuai dengan pantun-pantun yang ingin diwujudkan untuk pencapaian karya ini. Kolom A akan menjadi bagian 1 pada karya ini, kolom B menjadi bagian 2, dan kolom $\mathrm{C}$ menjadi bagian 3 .

Pada bagian 1 Konsep musik yang dihadirkan yaitu menggunakan beberapa rangkaian melodi pokok dengan pola ritme joget gamat, menggunakan teknik repetisi, kanon, penggunaan tempo yang relatif cepat. Pola ritme gamat dihadirkan dalam bentuk loop. Pada bagian ini pengkarya menghadirkan bunyi loop tersebut berada pada frekuensi $5 \mathrm{khz}-$ 20khz, karakter bunyi yang dihasilkan cendrung terang (mid high-high), bunyi loop ini terksesan samar-samar, namun loop ini berperan sebagai metronome untuk bagian ini. Kemudian menyanyikan pantun dengan makna yang mudah dicerna dan syair yang tidak terlalu panjang (sesuai sebagaimana biasanya permainan baru dimulai, dihadirkan dengan pantun yang relatif pendek), angka yang dikeluarkan 10 angka dengan 10 macam pantun. Pada bagian 1 ini terdapat part intro, kemudian pantun untuk 5 buah angka, lalu part interlude dengan mengguncang kaleng dan mengeluarkan 5 buah angka kembali, kemudian transisi untuk musik bagian ke 2.

Pada bagian 2 menggambarkan permainan KIM memberi suatu 
kecanduan, sehingga ingin untuk tetap melanjutkan permainan ini, biasanya yang menjadi salah satu faktornya dikarenakan sebelumnya belum mendapatkan hadiah / ingin mendapatkan hadiah yang banyak. Konsep musik yang dihadirkan yaitu menghadirkan hasil eksplorasi dan eksperimen yang telah dilakukan, lalu hasil tersebut menjadi sebuah bunyi yang dominan pada bagian ini, bunyi tersebut menyerupai aslinya atau berubah dari kaidah bunyinya sendiri, kemudian melakukan pengembangan tema melodi, dengan teknik repetisi, kanon, menggunakan modus fryghian, lalu mengolah ritme melodi tersebut serta mengolah pola ritme joget gamat, dan penggunaan tempo yang relatif cepat. Pola ritme gamat dalam bentuk loop masih dipertahankan pada bagian ini. Bunyi loop pada bagian ini berada pada frekuensi 350hz-10khz, karakter bunyi yang dihasilkan cendrung gelap dan terang (mid low-high), bunyi loop ini terksesan sedikit berani dan lebih memperdengarkan keberadaannya, loop ini memiliki peran yang lebih kuat sebagai metronome. Selain menghadirkan loop pengkarya juga menghadirkan sound yang identik dengan musik disco, edm, trance, sejenisnya, karena terdapat kemiripan pada musik pengiring KIM pada hari ini. Sound yang dihadirkan yaitu, mendominankan sound sawlead, pad synth, sound $f x$ lainnya. Kemudian menyanyikan pantun dengan makna kiasan, pantun yang menggambarkan suatu daerah, angka yang dikeluarkan 10 angka dan 10 macam pantun. Pada bagian 2 ini setelah transisi dari bagian 1, kemudian menyampaikan 5 buah pantun untuk 5 angka, lalu part interlude dengan mengguncang kaleng dan mengeluarkan 5 buah angka kembali, kemudian transisi untuk musik bagian ke 3 .

Pada bagian 3 menggambarkan keinginan untuk mendapatkan hadiah utama, karena biasanya pada akhir permainan KIM ada hadiah utama yang ada nilai jualnya. Pada bagian 3 ini pengkarya menterjemahkan keadaan tersebut pada komposisi musik barat. Konsep musik yang dihadirkan yaitu, menggabungkan melodi bagian 1 dan 2, serta menghadirkan hasil eksplorasi dan eksperimen, menggunakan modus fryghian, menggunakan chord add9 atau menyelipkan nada 9 dari setiap melodi yang dimainkan sehingga memberi kesan perasaan yang berkecamuk, lalu menggunakan pola ritme joget gamat dan menonjolkan bunyi low frequency yang dominan dengan tempo yang relatif cepat. Pola ritme gamat dalam bentuk loop masih dipertahankan pada bagian ini. Bunyi loop pada bagian ini berada pada frekuensi $20 \mathrm{hz}-20 \mathrm{khz}$, karakter bunyi yang dihasilkan cendrung jelas (lowmid low-mid high-high), bunyi loop ini terksesan sangat jelas dan lebih memperdengarkan keberadaannya, loop ini memiliki peran yang sangat kuat sebagai metronome. Namun bunyi loop ini diberi efek flanger terdengar seolah bunyi tersebut berputar-putar. Efek bunyi seperti ini memberi esensi, kesan keadaan yang sedang hiruk. Selain menghadirkan loop pengkarya juga menghadirkan sound yang identik dengan musik disco, edm, trance, sejenisnya, karena terdapat kemiripan pada musik pengiring KIM pada hari ini. Sound yang akan dihadirkan yaitu, mendominankan sound sawlead, pad synth, sound $f x$ lainnya. Begitu juga dengan permainan sound sawlead, pad synth, sound $f x$, peran sound ini 
memberikan kesan yang sesuai dengan sub judul pada bagian ini. Dari 3 bagian bentuk musik programa ini, musik cendrung menggambarkan makna yang tersirat dari pantunpantun yang akan pengkarya kutip untuk karya ini.

\section{KESIMPULAN}

Komposisi musik dengan judul Permainan KIM merupakan komposisi yang terinspirasi dari fenomena yang eksis dalam kehidupan masyarakat pada hari ini. Bercerita tentang sisi, pesan dan makna dari pantun, emosional yang terjadi pada permainan tersebut. Komposisi ini dibagi menjadi tiga bagian yang berkaitan dengan lapiak KIM yang terdiri dari kolom A, B, C. Digarap dengan metoda musik programa yang menggunakan perangkat musik elektronik. Pengkarya melihat fenomena tersebut sebagai sebatas hiburan yang terjadi ditengah kehidupan masyarakat. Untuk itu pengkarya mempresentasikannya lewat media seni musik barat. Komposisi musik elektronik sebagai teknik dalam menggarap bunyi sangat relevan untuk di presentasikan. Dengan ide musikal yang berangkat dari melodi sebuah lagu yang sudah ada semenjak permainan KIM dilakukan inspirasi dalam pengambilan unsur melodi, pengkarya menghadirkan bentuk-bentuk gagasan bunyi antara ruang dan waktu dalam permainannya. Baik secara teoritik maupun teknis aplikasinya.

\section{DAFTAR PUSTAKA}

Suryajaya, Martin. (2016) Sejarah Estetika. Jakarta: Penerbit Gang Kabel dan Indie Book Corner.

Sunarto, Bambang. (2013). Epistimologi Penciptaan Seni. Yogyakarta: IDEA Press.

Prier, Karl Edmund. (1993). Sejarah Musik Jilid 2. Yogyakarta: Pusat Musik Liturgi.

Mack, Dieter. (1995). Sejarah Musik Jilid 3. Yogyakarta: Pusat Musik Liturgi.

Mack, Dieter. (1995). Sejarah Musik Jilid 4. Yogyakarta: Pusat Musik Liturgi.

Pasaribu, M Ben. (2008). Musik Populer: Buku Pelajaran Kesenian Nusantara. Jakarta: Lembaga Pendidikan Seni Nusantara.

Inyiak Baron (?) pada Wawancara tanggal 10 November 2018

\section{WEBTOGRAFI}

https://id.m.wikipedia.org/wiki/perm ainan

https://www.ilmuseni.com 